\title{
Pre-College Influences and College Major Choice: Gender, Race/Ethnicity and Nativity Patterning
}

\author{
Yingyi $\mathrm{Ma}^{1}$
}

This paper gives a comprehensive examination on patterns of the initial college major choice for gender, racial/ethnic and nativity groups. I focus on the influence of three aspects of pre-college experiences: achievement, attitude and course taking in both math and English. I find math matters more than English in determining college major choice. Math attitude remains as the most important factor in contributing to gender differences in college major choice. Racial minorities share the tendency in choosing more lucrative college majors than whites. [Article copies available for a fee from The Transformative Studies Institute.E-mail address: journal@transformativestudies.org Website: http://www.transformativestudies.org (2009 by The Transformative Studies Institute. All rights reserved.]

KEYWORDS: Gender, Race, Ethnicity, Nativity, College Major.

\section{INTRODUCTION}

College major choice, like any decision making, is associated with uncertainty. With rising tuition and the unstable economy, this uncertainty is magnified. Studies have reported that degrees in engineering, computer science and business gain higher earnings returns, while degrees in humanities, social science and education produce lower returns (Hecker 1995; Marini and Fan 1997). This has led some scholars to ponder upon the implications of college major choice for life chances. Gerber (2004)

\footnotetext{
${ }^{1}$ Yingyi Ma, Ph.D., is Assistant Professor in Sociology, Maxwell School of Citizenship and Public Affairs, Syracuse University. She obtained her PhD in Sociology from Johns Hopkins University in Baltimore, Maryland. She is currently teaching undergraduate sociology of gender course and graduate social statistics course. Dr. Ma's research takes a multidisciplinary approach to examining issues that have both theoretical and practical implications. Specifically, she has research interests in education and social inequality, paying particular attention to gender and racial differences in higher education and the ensuing labor market outcomes. Address correspondence to: Yingyi Ma, Maxwell School of Citizenship and Public Affairs, 302 Maxwell, Syracuse University, Syracuse, NY 13244; tel: (315)-443-3716; e-mail: Email: yma03@maxwell.syr.edu.
} 